\title{
Cikkismertetés: A fizikai aktivitás során bekövetkezett változások mérése intervenciós vizsgálatokban
}

\author{
Article review: Measuring change in trials of physical activity interventions: \\ a comparison of self-report questionnaire and accelerometry within the \\ PACE-UP trial
}

Ismertető: $\quad$ Hanzel Adrienn $\square$

Pécsi Tudományegyetem Általános Orvostudományi Kar Orvosi Népegészségtani Intézet

Ismertetett cikk: Limb ES, Ahmad S, Cook DG et al. Measuring change in trials of physical activity interventions: a comparison of self-report questionnaire and accelerometry within the PACEUP trial. Int J Behav Nutr Phy. 2019;16(1):10 doi: 10.1186/s12966-018-0762-5

Beküldve: $\quad$ 2019. 05. 30.

doi: $\quad$ 10.24365/ef.v61i1.478

Kulcsszavak: séta; intervenció; alapellátás; akcelerometria; IPAQ

Keywords: walking; intervention; primary care; MVPA; accelerometry; IPAQ

\section{BEVEZETÉS}

Néhány tanulmány összehasonlította a fizikai aktivitás változását önbevallásos kérdőívvel, illetve objektív mérési módszerekkel is. Jelen esetben a PACE-UP vizsgálat adott erre lehetőséget, melyben az önbevalláson alapuló „Nemzetközi Fizikai Aktivitási Kérdőívet” (International Physical Activity Questionnaire, IPAQ), valamint a derékra szerelhető akcelerométert, azaz mozgásmérő szerkezetet alkalmazták.

\section{MÓDSZEREK}

A PACE-UP vizsgálat ( $n=1023$ ) két lépésszámlálót alkalmazó intervenciós eljárással hasonlította össze a kontrollcsoportot ( $n=338)$. Az adatgyújtést levél útján ( $n=339$ ) vagy ápolók közremúködésével ( $n=346$ ) végezték. A résztvevők a vizsgálat indulásakor és az azt követő 12 . hónapban is 7 napon keresztül akcelerométert viseltek, és ugyanebben az időszakban töltötték ki az IPAQ kérdőívet is. A vizsgálat fókuszában a hetente percekben mért fizikai aktivitás állt az Egyesült Királyság irányelveit figyelembe véve. Ezek alapján sorolták be a kapott eredményeket három fó kategóriába abban az esetben, ha egy alkalom meghaladta a 10 percet: 1) akcelerométer mérsékelt-magas intenzitású fizikai aktivitás (Acc-MVPA); 2) IPAQ mérsékelt+magas intenzitású fizikai aktivitás és 3) IPAQ-séta (IPAQ-Walk). Minden esetben a 12 hónap eredményét hasonlították a kiindulási értékhez a változás meghatározása érdekében.

\section{EREDMÉNYEK}

Az elemzések 655 (64\%) résztvevőre vonatkoztak, akik elegendő adatot szolgáltattak mind a kiinduláskor, mind az egy évvel későbbi utánkövetéses mérés során. Mindkét intervenciós csoport jelentősen megnövelte az akcelerométer mérsékelt-magas intenzitású fizikai aktivitás perc/hét mértékét 
a kontrollhoz viszonyítva: a levelezős csoportnál 42 (95\% KI 22,61), a nővér által támogatott csoportnál 43 (95\% KI 24,63) lett a kapott értéke. Az IPAQséta perc/hét érték szintén emelkedett, a levelezős csoportnál 57 (95\% KI 2,112), a nővér által támogatott csoportnál 43 (95\% KI -11,97) értéket kaptak a vizsgálat során. Azonban az IPAQ-MVPA perc/hét érték mind a levelezős csoportnál -11 (95\% KI -65, 42), mind a nővér által támogatott csoportnál -34 (95\% KI -87,19) nem szignifikáns mértékű csökkenést mutatott.

\section{KÖVETKEZTETÉSEK}

A kutatók eredményei azt mutatják, hogy szükség van olyan kérdőív használatára, amely a változó fizikai aktivitásra összpontosít, ahogyan az IPAQ-séta kérdések esetében van. Még akkor is szükséges ez, ha a fizikai aktivitás változásának meghatározása sokkal pontatlanabb ily módon, mint akcelerometriával. Az aktivitásmérő jobb eredményeket mutat az önbevallásos kérdőívhez képest, minimalizálja a torzítást, és javítja a pontosságot.

\section{TANULSÁGOK A HAZAI SZAKEMBEREK SZÁMÁRA}

A fizikai aktivitás mérése szempontjából szükség van olyan kérdőívre, ami a változó fizikai aktivitásra összpontosít. Az aktivitásmérő alkalmazása egyszerü, és pontosabb eredményeket mutat az adott személy fizikai állapotáról, így a hazai gyakorlatban is hatékonyan alkalmazható lenne ez a fajta megközelítés. Ezekkel a módszerekkel átfogóbb képet kaphatunk a vizsgált személy egészségére vonatkozóan. 